\title{
Neuro epidemiology
}

Founded 1982 by B.S. Schoenberg, continued by M. Alter (1989-1996), P.B. Gorelick (1997-2000) and G.C. Román (2001-2007)

\section{Editor-in-Chief}

V.L. Feigin, Auckland

\section{Associate Editors}

G. Donnan, Melbourne

A. Hofman, Rotterdam

G. Logroscino, Boston, Mass.

\section{Assistant Editor}

J.A. Ford, Auckland

\section{Editorial Board}

G.B.J. Anderson, Chicago, Ill.

A. Barber, Auckland

S. Barker-Collo, Auckland

E. Beghi, Milano

D.A. Bennett, Chicago, Ill.

D. Bennett, Oxford

F. Bermejo, Madrid

N.E. Bharucha, Mumbai

G. Boysen, Copenhagen M.M.B. Breteler, Rotterdam

A. Culebras, Syracuse, N.Y.

R. D’Alessandro, Bologna

J.F. Dartigues, Bordeaux

J.L. Fisher, Columbus, Ohio

G.M. Franklin, Seattle, Wash.

A.J. Hannan, Melbourne

G. Hankey, Perth

W.A. Hauser, New York, N.Y.

C. Ketzoian, Montevideo

S.J. Kittner, Baltimore, Md.
A. Korczyn, Tel-Aviv J.F. Kurtzke, Falls Church, Va. S.-M. Lai, Kansas City, Kans. M. Liu, Chengdu E.D. Louis, New York, N.Y. K. McPherson, Auckland K. Nakashima, Yonago L. Nelson, Stanford, Calif. B. Norrving, Lund P.-M. Preux, Limoges A.H. Rajput, Saskatoon K. Rockwood, Halifax R.L. Sacco, Miami, Fla. W.F. Stewart, Danville, Pa. M. Thrift, Melbourne

T. Truelsen, Copenhagen J. Tuomilehto, Helsinki C. Tzourio, Paris H. von Holst, Stockholm 
S. Karger

Medical and Scientific Publishers

Basel $\cdot$ Freiburg $\cdot$ Paris $\bullet$ London •

New York $•$ Bangalore $\cdot$ Bangkok

Shanghai $\cdot$ Singapore $\cdot$ Tokyo $\cdot$ Sydney
Disclaimer

The statements, opinions and data contained in this publication are solely those of the individual authors and contributors and not of the publisher and the editor(s). The appearance of advertisements in the journal is not a warranty, endorsement or approval of the products or services advertised or of thei effectiveness, quality or safety. The publisher and the editor(s) disclaim responsibility for any injury to persons or property resulting from any ideas, methods, instructions or products referred to in the content or advertisements.

Drug Dosage

The authors and the publisher have exerted every effort to ensure that drug selection and dosage set forth in this text are in accord with current recommendations and practice at the time of publication. However, in view of ongoing research, changes in government regulations, and the constant flow of information relating to drug therapy and drug reactions, the reader is urged to check the package insert for each drug for any change in indications and dosage and for added warnings and precautions. This is particularly important when the recommended agent is a new and/or infrequently employed drug.
All rights reserved.

No part of this publication may be translated into other languages, reproduced or utilized in any form or by any means, electronic or mechanical, including photocopying, recording, microcopying, or by any information storage and retrieval system, without permission in writing from the publisher or, in the case of photocopying, direct payment of a specified fee to the Copyright Clearance Center (see 'General Information')

(c) Copyright 2008 by S. Karger AG

P.O. Box, CH-4009 Basel (Switzerland)

Printed in Switzerland

on acid-free and non-aging paper (ISO 9706) by

Reinhardt Druck, Basel

\section{KARGER}


No. 1

Review

1 Historical and Clinical Perspectives of the Expanded Disability Status Scale

Kurtzke, J.F. (Washington, D.C.)

Original Papers

10 Social Ties and Cognitive Recovery after Stroke: Does Social Integration Promote Cognitive Resilience?

Glymour, M.M. (New York, N.Y./Boston, Mass.); Weuve, J.; Fay, M.E.

(Boston, Mass.); Glass, T. (Baltimore, Md.); Berkman, L.F. (Boston, Mass.)

21 Education-Related Differences in Case Fatality among Elderly with Stroke

Löfmark, U.; Hammarström, A. (Umeå)

28 Amyotrophic Lateral Sclerosis among 1991 Gulf War Veterans: Evidence for a Time-Limited Outbreak

Horner, R.D. (Cincinnati, Ohio); Grambow, S.C.; Coffman, C.J.; Lindquist, J.H.; Oddone, E.Z.; Allen, K.D. (Durham, N.C.); Kasarskis, E.J. (Lexington, Ky.)

33 Stroke among Siblings in a Biethnic Community Lisabeth, L.D.; Peyser, P.A.; Long, J.C.; Majerisk, J.J.; Smith, M.A.; Morgenstern, L.B. (Ann Arbor, Mich.)

39 Lifestyle and Memory in the Elderly Flöel, A.; Witte, A.V.; Lohmann, H.; Wersching, H.; Ringelstein, E.B.; Berger, K.; Knecht, S. (Münster)

48 The Effect of Statin Pretreatment on Infarct Volume in Ischemic Stroke

Nicholas, J.S.; Swearingen, C.J.; Thomas, J.C.; Rumboldt, Z.; Tumminello, P.; Patel, S.J. (Charleston, S.C.)

Methods in Neuroepidemiology

57 Calculation of Prevalence Estimates through Differential Equations: Application to Stroke-Related Disability

Mar, J.; Sainz-Ezkerra, M. (Mondragon); Moler-Cuiral, J.A. (Pamplona)

Letter to the Editor

67 Cardiovascular Risk Factors in Vascular Dementia and Ischaemic Stroke

Potluri, R.; Natalwala, A.; Uppal, H.; Heun, R. (Birmingham)

Comment

68 Risk Factors for Dementia

Thrift, A.G.; Srikanth, V.K. (Melbourne, Vic.)

\section{No. 2}

Methods in Neuroepidemiology

69 Predictive Factors of Attrition in a Cohort of Alzheimer Disease Patients. The REAL.FR Study

Coley, N.; Gardette, V.; Toulza, O.; Gillette-Guyonnet, S.; Cantet, C.; Nourhashemi, F.; Andrieu, S.; Grand, A.; Vellas, B. (Toulouse)

Original Papers

80 Mortality after a Diagnosis of Dementia in a Population Aged 75 and Over in Spain

Llinàs-Regla, J.; López-Pousa, S.; Vilalta-Franch, J.; Garre-Olmo, J. (Salt); Román, G.C. (San Antonio, Tex.)

89 Prothrombotic Gene Variation in Patients with Large and Small Vessel Disease

Pruissen, D.M.O.; Kappelle, L.J. (Utrecht); Rosendaal, F.R. (Leiden); Algra, A (Utrecht/Leiden) on behalf of the SMART Study Group

93 Hospital Admissions for Stroke among the Very Old in the USA Tabereaux, P.B. (New Haven, Conn.); Brass, L.M.; Concato, J. (West Haven, Conn./New Haven, Conn.); Bravata, D.M. (Indianapolis, Ind./ West Haven, Conn./New Haven, Conn.)

100 Time until Institutionalization in Incident Dementia Cases Results of the Leipzig Longitudinal Study of the Aged (LEILA 75+)

Luck, T.; Luppa, M.; Weber, S.; Matschinger, H.; Glaesmer, H.; König, H.-H. (Leipzig); Angermeyer, M.C. (Gösing a. W.); Riedel-Heller, S.G. (Leipzig)

109 Cognitive Dysfunction in an Urban Indian Population Some Observations

Banerjee, T.K.; Mukherjee, C.S.; Dutt, A.; Shekhar, A.; Hazra, A. (Kolkata)

115 The Association between Heart Rate Variability and Cognitive Impairment in Middle-Aged Men and Women. The Whitehall II Cohort Study

Britton, A. (London); Singh-Manoux, A. (London/Villejuif); Hnatkova, K.; Malik, M.; Marmot, M.G.; Shipley, M. (London)

122 Epidemiology, Characteristics and Distinctiveness of Headaches in Children from Vojvodina, Serbia Knežević-Pogančev, M. (Novi Sad)

Review

129 The Prevalence of Multiple Sclerosis in the Middle East Al-Hashel, J.; Besterman, A.D.; Wolfson, C. (Montreal, Que.)

Letters to the Editor

138 Body Mass Index, Cholesterol Level and Poststroke Mortality Mascitelli, L. (Udine); Pezzetta, F. (Tolmezzo); Goldstein, M.R. (Bonita Springs, Fla.)

138 Reply to the Letter by Mascitelli et al.: Body Mass Index, Cholesterol Level and Poststroke Mortality Olsen, T.S. (Hvidovre); Dehlendorff, C.; Petersen, H.G.; Andersen, K.K. (Lyngby)

\section{KARGER}

Fax +4161306 1234 E-Mail karger@karger.ch www.karger.com

\section{(C) 2008 S. Karger AG, Base}

Access to full text and tables of contents, including tentative ones for forthcoming issues: www.karger.com/ned_issues 
No. 3

Review

139 Environmental Epidemiology of Essential Tremor Louis, E.D. (New York, N.Y.)

Original Papers

150 Clinical Parameters to Predict Response to Interferon in Relapsing Multiple Sclerosis

Fromont, A. (Dijon); Debouverie, M. (Vandoeuvre-lès-Nancy); Le Teuff, G.; Quantin, C.; Binquet, C.; Moreau, T. (Dijon)

159 Epidemiology and Medical Expenses of Motor Neuron Diseases in Taiwan

Lai, C.-H. (Changhua); Tseng, H.-F. (Kaohsiung)

167 Functional Decline in Cognitive Impairment The Relationship between Physical and Cognitive Function Auyeung, T.W.; Kwok, T.; Lee, J.; Leung, P.C.; Leung, J.; Woo, J. (Hong Kong)

174 Respiratory Muscle Strength Predicts Decline in Mobility in Older Persons

Buchman, A.S.; Boyle, P.A.; Wilson, R.S.; Leurgans, S.; Shah, R.C.; Bennett, D.A. (Chicago, Ill.)

181 No Effect of Birth Weight on the Risk of Multiple Sclerosis A Population-Based Study

Ramagopalan, S.V; Herrera, B.M.; Valdar, W.; Dyment, D.A.; Orton, S.-M. (Oxford); Yee, I.M.; Criscuoli, M.; Atkins, K. (Vancouver, B.C.); Ebers, G.C. (Oxford); Sadovnick, A.D. (Vancouver, B.C.) for the Canadian Collaborative Study Group

185 Fertility in Essential Tremor. Data from Population-Based and Clinical Sources

Louis, E.D. (New York, N.Y.)

193 Evaluation of the Impact of Memantine Treatment Initiation on Psychotropics Use: A Study from the French National Health Care Database

Vidal, J.-S.; Lacombe, J.-M. (Paris); Dartigues, J.-F. (Bordeaux); Pasquier, F. (Lille); Robert, P. (Nice); Tzourio, C.; Alpérovitch, A. (Paris)

Comments

157 The Treatment of Multiple Sclerosis with Beta-Interferon Poser, C.M. (Boston, Mass.)

191 Essential Tremor: From a Monosymptomatic Disorder to a More Complex Entity

Benito-León, J. (Madrid)

\section{No. 4}

Abstracts

201 XIIIth National Meeting of the Italian Neuroepidemiology Association

Verona, Italy, September 26-28, 2008

Chairperson: Chió, A. (Torino)

(available online only)

Original Papers

224 Population Stratification in a Case-Control Study of Brain Arteriovenous Malformation in Latinos

Kim, H.; Hysi, P.G.; Pawlikowska, L.; Choudhry, S.; González Burchard, E.; Kwok, P.Y. (San Francisco, Calif.); Sidney, S. (Oakland, Calif.);

McCulloch, C.E.; Young, W.L. (San Francisco, Calif.)
229 Surgery and Risk of Sporadic Creutzfeldt-Jakob Disease in Denmark and Sweden: Registry-Based Case-Control Studies Mahillo-Fernandez, I.; de Pedro-Cuesta, J.; Bleda, M.J. (Madrid); Cruz, M. (Stockholm); Mølbak, K.; Laursen, H.; Falkenhorst, G. (Copenhagen); Martínez-Martín, P. (Madrid); Siden, Å. (Stockholm) on behalf of the EUROSURGYCJD Research Group

Comment

241 Surgery and Risk of Sporadic Creutzfeldt-Jakob Disease Ward, H.J.T.; Knight, R.S.G. (Edinburgh)

Original Paper

243 The Prevalence, Correlates and Impact of Dementia in Cuba A 10/66 Group Population-Based Survey

Llibre Rodríguez, J. (Havana); Valhuerdi, A. (Matanzas); Sanchez, I.I. (Havana); Reyna, C. (Matanzas); Guerra, M.A. (Havana); Copeland, J.R.M. (Liverpool); McKeigue, P. (Dublin); Ferri, C.P.; Prince, M.J. (London)

Comment

252 Dementia in Latin America and the Caribbean: An Overlooked Epidemic

Maestre, G.E. (Maracaibo/New York, N.Y.)

Original Paper

254 Population-Based Stroke Survey in Mumbai, India: Incidence and 28-Day Case Fatality

Dalal, P.M.; Malik, S.; Bhattacharjee, M.; Trivedi, N.D.; Vairale, J.; Bhat, P.; Deshmukh, S.; Khandelwal, K.; Mathur, V.D. (Mumbai)

Comment

262 Experiences from the Mumbai Stroke Register Truelsen, T. (Copenhagen)

Original Paper

264 Epidemiology of Gliomas in Israel: A Nationwide Study Sadetzki, S. (Tel Hashomer/Tel-Aviv); Zach, L.; Chetrit, A.; Nass, D. (Tel Hashomer); Hoffmann, C. (Tel Hashomer/Tel-Aviv); Ram, Z. (Tel-Aviv); Zaaroor, M. (Haifa); Umansky, F. (Jerusalem/Detroit, Mich.); Rappaport, Z.H. (Tel-Aviv/Petah-Tiqva); Cohen, A. (Beer-Sheva); Wald, U. (Tel-Aviv); Rothman, S. (Zerifin); Hadani, M. (Tel Hashomer/Tel-Aviv)

Comment

270 Glial Brain Tumors

Idowu, O.E. (Ikeja)

Original Paper

271 Monthly Ambient Sunlight, Infections and Relapse Rates in Multiple Sclerosis

Tremlett, H. (Vancouver, B.C.); van der Mei, I.A.F.; Pittas, F.; Blizzard, L.; Paley, G.; Mesaros, D.; Woodbaker, R.; Nunez, M. (Hobart, Tas.); Dwyer, T. (Hobart, Tas./Melbourne Vic.); Taylor, B.V. (Hobart, Tas.); Ponsonby, A.-L. (Hobart, Tas./Melbourne Vic.)

Comments

280 Sunshine on MS

Kesselring, J. (Valens)

282 Prothrombotic Gene Variations in Ischemic Stroke: No Differences between Large and Small Vessel Disease? Jungehulsing, G.J.; Nolte, C.H. (Berlin)

283 Acknowledgements to Referees

285 Author Index Vol. 31, 2008

286 Subject Index Vol. 31, 2008 